\title{
Role historie v době post-faktické 1
}

\author{
David Černín \\ Centrum pro studium středověké společnosti a kultury - VIVARIUM \\ Filozofická fakulta \\ Ostravská univerzita \\ Reální 5, 70103 Ostrava \\ cernin.d@gmail.com
}

Jaká je role historie v době post-faktické? Může nám filosofie historie pomoci bránit se proti cílenému zneužívání historických narativů na ideologickém základě? Tento článek zkoumá filosofické reflexe historie a jejich vztah k ideologiím. Je ukázáno, že na počátku této filosofické disciplíny filosofové jako Karl Popper nebo C. G. Hempel usilovali o eliminaci politického a ideologického zabarvení historie. Avšak narativistické bádání Haydena Whita naznačuje, že takový cíl je nedosažitelný. Antirealistická filosofie historie, zastoupena L. J. Goldsteinem, dokonce odmítá reálnou minulost jako cíl historického bádání a zdůrazňuje situovanost historiků ve vztahu $\mathrm{k}$ důkazům. Představená verze historického antirealismu chápe historii jako současné zkoumání, které sdílí řadu rysů s kritickým myšlením a zaměřuje se především na zkoumání empirických dat, jež vyžadují postulaci nepřístupné minulosti. Tato podobnost by měla být zdůrazněna skrze výuku historie jako zkoumání, nikoliv jako pouhého př́běhu.

Klíčová slova: filosofie historie, narativismus, antirealismus, kritické myšlení

1 Tento článek vzniknul za podpory IRP projektu řešeného na Ostravské univerzitě: IRP201820 „The Construction of the Other in Medieval Europe“ (IRP University of Ostrava). Rád bych zde také poděkoval oběma anonymním recenzentům za cenné postřehy a návrhy na vylepšení finální podoby článku. 


\section{Úvod}

Doba post-faktická, ${ }^{2}$ pro niž jsou příznačné dezinformace, falešné zprávy, zneužívání médií a konstantní snaha o ovlivnění veřejného mínění za pomocí pochybných praktik, zahrnuje pestrou škálu diskursů a různorodé zainteresované subjekty cílevědomě implementující nástroje a poznatky odborných disciplín takovým způsobem, který potvrzuje a prosazuje jejich narativ, politické přesvědčení či vizi světa. Tento článek se zaměřuje na jednu z takto zneužívaných disciplín - historii. Historické poznání ve formě historických teorií či narativů je notoricky známé jak pro svou ohebnost, ${ }^{3}$ tak pro svi̊j vliv na veřejné mínění a budování společenské identity. ${ }^{4}$ Historie se zdaleka neocitá pod kritickým drobnohledem poprvé - pravidelně se objevují texty vyvracející rozličné pokusy o predikce historického vývoje, kritizující hlasatele blížícího se kolapsu či jiné přesvědčené proroky čerpající ponaučení z minulosti. Přímé útoky na rozporuplnou pragmatickou hodnotu historického poznání zpravidla opakují léty prověřenou formuli Karla Poppera, podle níž nelze vědecky předvídat budoucí vývoj lidských dějin. ${ }^{5}$

Je ovšem nutné podotknout, že ne všechny výpady na moderním kolbišti dezinformací, vedené s využitím historie, mají podobu přímočaré predikce. Ve veřejném diskursu se setkáváme s celou řadou cíleně formulovaných analogií $\mathrm{k}$ historickým událostem či je zvykem v minulosti hledat hodnoty a zásady, jichž se nám nyní nedostává. Je těžké se při sledování právě probíhajících společenských a politických událostí

2 Přesné definování pojmu doba post-faktická či post-pravdivá není cílem tohoto článku. O jeho definování usiluje celá řada odborných textů, které rovněž poukazují na obtíže jednoznačného vymezení a také na skutečnost, že přidružené termíny (nap̌̌r. „fake news“) jsou často užívány různorodě (viz Harsin (2018), Hayhoe (2017), Heit (2018)). Pro potřeby tohoto článku bude doba post-faktická chápána jako období počínající rokem 2016, pro nějž byly příznačné události jako hlasování o odchodu Velké Británie z EU a zvolení prezidenta USA Donalda Trumpa. Různé definice doby post-faktické zmiňují změny v tom, jak společnost nahlíží na pojem objektivní pravdy, nárůst nedůvěry v expertní vědění, nadřazení osobních přesvědčení a emocí nad objektivní fakta a šíření „fake news“v mediích a na sociálních sítích.

3 Ohebnost historického poznání dokládají jak lidová pořekadla typu „dějiny píší vítězové“, tak řada teoretických a filosofických analýz, zejména v dílech narativisticky orientovaných filosofü.

$4 \mathrm{~V}$ českém prostředí je toto evidentní již od dob sporu o rukopisy, které byly využity v rámci Národního obrození. Vztah historických teorií a budování národní identity je specifickým problémem teorií národa a nacionalismu, viz např. Smith (2000) či Horský (2008). Tendence odvolávat se na různorodé historické teorie je ovšem patrná ve veřejném prostoru také dnes.

5 Viz Popper (1957, s. ix-x). 
ubránit téměř podvědomému srovnávání s událostmi z učebnic dějepisu a od obdobných paralel je to již jen krok ke groteskním prohlášením typu „skončíme jako řriše římská“. Svou roli zde hraje celá řada kognitivních zkreslení, zahrnujících zejména klam zpětného hodnocení (hindsight bias), ${ }^{6}$ efekt nadměrné sebedůvěry (overconfidence bias) a potvrzovací slepotu (confirmation bias). Zároveň se pak zdá, že různé varianty historických narativů lze použít k lidovému ospravedlnění zcela protichůdných normativních tvrzení, což je mimo jiné důsledek faktu, že v komunitě historiků běžně koexistují kompetitivní teorie a vysvětlení historických událostí, a ne vždy mezi odborníky panuje naprostý konsensus. Svůj podíl na tom má rovněž převládající narativní podoba výstupů historického výzkumu. Poukaz na historický výzkum či na „slavnou minulost“ propůjčuje zdánlivou kredibilitu leckdy protichůdným politickým stanoviskům a vhodná volba historického narativu může implicitně působit na čtenáře či posluchače.

Palčivost politického pozadí historických narativi̊ a jejich vlivu na širokou společnost byla rovněž identifikována autory nedávno vydané Výroční zprávy Bezpečnostní informační služby za rok 2017, v níž se v poznámce pod čarou dočteme:

\begin{abstract}
„Moderní dějiny prezentované ve školách jsou de facto sovětskou verzí moderních dějin a proruským panslovanstvím je do jisté míry zasažena i výuka českého jazyka, resp. literatury (národní obrození). Trvající vliv sovětské propagandy a fakt, že Rusové ovládají moderní dějiny (Orwell: Kdo ovládá minulost, ovládá budoucnost. Kdo ovládá současnost, ovládá minulost.), tvoří základ pro současné ruské vlivové operace všeho druhu a tedy i hybridní strategie.“7
\end{abstract}

Společenská diskuse, kterou následující poznámka vyvolala, pak jasně ukazuje, že lidé chovají k historickým narativům, jež jsou vyučovány ve škole a reprezentovány v kultuře, určitou emocionální vazbu a odmítají kritiku takových narativů, třebaže pochází od odborníků.

6 Viz Trout (2002).

7 Bezpečnostní informační služba (2018, s. 7). 
Je možné namítnout, že se v předcházejících odstavcích nerozlišuje mezi odbornou (vědeckou) historií, a „lidovou historii“ (folk history), popř. že nejsou reflektovány složitější vztahy mezi akademickou historií (scholarly history), populární historií (popular history) a veřejnou historií (public history). $\mathrm{V}$ praxi jsou ovšem tyto rozdíly často nejasné a jednotlivé položky jsou vzájemně dynamicky propojené. Jedna z publikací, která tento aspekt velmi dobře mapuje, je kniha zasloužilého finského historika Jormy Kalely Making History z roku 2012. Kalela zde popisuje své zkušenosti jakožto začínajícího historika, který se od 70. let 20. století věnuje dějinám papírenského průmyslu ve Finsku, využívá pokročilých metod orální historie a skupinových seminářù vedených pracovníky jednotlivých závodů. Kalela poznamenává, že lidé, navzdory elitářskému postoji historiků, vytvářejí či konstruují vlastní historie. Zároveň je ovšem nutno neopomenout, že také profesionální historikové tuto skutečnost reflektují (vědomě či nevědomě) a zohledňují ji při volbě tématu svého výzkumu a formy zpracování:

\section{„Hlavní lekce spočívala v tom, že vnímavý historik neuvažu- je o svém obecenstvu jako o pouhých konzumentech objevů ,specialistů‘, ale jako o lidech, kteří vytvářejí své vlastní his- torie - velmi často bez našeho přispění."}

V článku se tedy budu věnovat primárně akademické historii, ačkoliv řada aspektů těchto forem historie se vzájemně prolíná a ovlivňuje. Odborné historické bádání ovlivňuje veřejný historický diskurs a ten zase ovlivňuje současné badatele, kteří odpovídají na otázky palčivé pro jejich předpokládané publikum.

Na rozdíl od popperovské kritiky historicismu a odmítnutí pragmatické hodnoty historického výzkumu je tento článek pokusem jít odlišným směrem, který má rovněž kořeny v angloamerické filosofii 40. let 20. století, a analyzovat současnou pozici historie optikou současné angloamerické filosofie historie. Cílem článku bude představit vybraná filosofická vymezení historie jako disciplíny a předložit přesnější vymezení historie tváŕí tvář nástrahám, které pro ni představuje doba post-faktická. Historický kon-

8 Kalela (2012, s. 57). 
struktivismus $\mathrm{s}$ příklonem $\mathrm{k}$ umírněnému historickému antirealismu bude představen jako preferovaná alternativa vůči historickému realismu či narativismu, která může nabídnout podněty a metody, jak vymezit historii proti dezinterpretaci a dezinformacím. Historický antirealismus zdůrazňuje zejména roli současného historického výzkumu a bádání proti poznání reálné minulosti. $\mathrm{V}$ popředí stojí identifikace a interpretace empirických dat ve formě artefaktů a textů jako důkazů pro teorie o konstruované historické minulosti. $\mathrm{V}$ závěru článku je pak naznačeno praktické využití tohoto pojetí historie ve formě důslednějšího zahrnutí interpretačních a heuristických cvičení do školní výuky a reprezentace výsledků historického bádání.

\section{Boj proti ideologii v historii}

$\mathrm{V}$ této části se budeme věnovat počátkům anglosaské diskuse o historii a zejména protiideologickému aspektu obsaženému v dílech dvou zásadních filosofů vědy, kteří sympatizovali s novopozitivismem a snažili se vědecké i historické bádání očistit od ideologie, - Karla R. Poppera a Carla G. Hempela.

Popperova argumentace proti historicismu a celková kritika historické interpretace byla zčásti motivována politickým vývojem ${ }^{9}$ a neutěšeným stavem společenských věd, které chtěl Popper bránit proti postupům a metodám vymykajícím se jeho filosofické koncepci vědy. Obdobná argumentace proti různorodým predikcím založeným na znalosti historických událostí se objevuje také dnes ${ }^{10}$ a rovněž v českém prostředí se najdou dobře odůvodněné texty upozorňující na přetrvávající nešvar. ${ }^{11}$ Filosofové, sociální vědci a ekonomové upozorňují především na komplexní povahu lidské společnosti a vysokou obtížnost hraničící s nemožností jakýchkoliv predikcí zaměřených na její historický vývoj. V Bídě historicismu Popper pouze výjimečně odkazuje ke „klasickým historikům“"12 a k tomu, jak se odlišuje jejich přístup $\mathrm{k}$ minulosti a $\mathrm{k}$ historii

\footnotetext{
9 Viz Birner (2018).

10 Rosenberg (2011).

11 Špecián (2016).

12 Popper (1957, s. 151): „classical historians“.
} 
jako disciplíně od přístupu kritizovaného historicismu. Podle Poppera „klasická historie“ sama nevědomky využívá univerzálních zákonitostí (ve formě vágních, triviálních tvrzení) $\mathrm{k}$ tomu, aby skrze kauzální př́íběh vysvětlila jednotlivé události. ${ }^{13}$

Srovnatelný, avšak na historii jako legitimní disciplínu více zaměřený, pohled nabízí jiný soudobý filosof pocházející ze střední Evropy, jehož politické změny a vzestup nacistické ideologie rovněž donutily k emigraci. Jeden ze svých prvních anglicky psaných článků Carl Gustav Hempel věnuje tématu, které se zdánlivě vymyká jeho zaměření na filosofii př́rodních věd. Ačkoliv se na první pohled nemusí zdát, že by článek „The Function of General Laws in History" z roku 1942 byl motivován politicky, je jeho načasování př́značné. Text nejenže vymezuje pojem pokrývajícího zákona ${ }^{14}$ ale zároveň $\mathrm{v}$ angloamerickém prostředí představuje počátek diskuse o historickém vysvětlování a potažmo také o povaze historické disciplíny. Hempel analyzuje historický modus vysvětlování jako jednu z mnoha instancí využití pokrývajícího zákona - explanandum (tvrzení o typu historické události, minulém stavu světa) je vysvětleno (tj. je možné jej deduktivně-nomologicky odvodit) skrze explanans (kombinace popisu předcházejících podmínek a formulovaných obecných zákonů). Hempel si je plně vědom, že běžné historické vysvětlení neodkazuje na pevně ustanovené obecné zákony, a tudíž historikové mnohdy svým čtenářům nabízejí spíše explanační náčrty (explanation sketches), ${ }^{15} \mathrm{kte}-$ ré mohou nasměrovat budoucí empirický výzkum a indikovat chybějící komponenty plnohodnotného vysvětlení. Obecné zákony jsou ovšem tiše předpokládány ${ }^{16} \mathrm{a}$ jsou nezbytné také $\mathrm{v}$ př́padech, kdy historik usiluje čistě o ryzí deskripci minulosti bez elementu vysvětlení, nebot' potřebuje propojit současná empirická data s nepř́ístupnou minulostí.

Hempela a Poppera tak ve vztahu $\mathrm{k}$ historii jako disciplíně sbližuje nejen důraz na deduktivněnomologickou složku historického vysvětlení, ale také nedůvěra k obtížně vymezitelným a empiricky nevymezitelným

\footnotetext{
13 Tamtéž, s. 150.
}

14 Překlad „pokrývající zákon“ (z anglického „covering law“) byl zvolen na základě dvou českých a jednoho slovenského překladu. Viz Hempel (1967) v překladu Petra Hromka, Zeleňák (2015), von Wright (1971) v překladu Petra Urbana a kol.

15 Hempel (1942, s. 42).

16 Tamtéž, s. 40. 
pojmům jako je „duch doby“"17, „empatické rozuměni“"18 či „historické směřování určité rasy“"19. Hempel se snaží o preciznější ukotvení a vymezení úlohy historiků ve vztahu $\mathrm{k}$ přírodním vědám, přičemž shledává, že tento úkol je velmi obtížný. Na rozdíl od Poppera se zdá, že Hempelův text neodkazuje na politické události, které ho donutily k emigraci, avšak odkazy na rasové teorie se opakovaně objevují jako příklad chybného komponentu historického vysvětlení.

Zároveň Hempel v roce 1939, krátce po svém prríchodu do USA, v rozhlasovém pořadu explicitně hovoří o tom, že cílem jeho filosofických snah je kritika nevědecké argumentace ve filosofii, která může poskytovat pseudovědecké ospravedlnění činů, které by jinak vědecky ospravedlnit nebylo možné, přičemž dodává: „A takové zneužití se událo.“ ${ }^{\circ 0}$

Dle Dewulfa tímto Hempel odkazuje k nástupu nacismu v Německu. Zdá se tedy, že určitý odpor k ideologickému pojetí historie je, přinejmenším implicitně, společný oběma autorům. Hempel a Popper chápou profesionální historii jako vědeckou disciplínu sdílející více či méně totožné metody a sledující obdobné cíle jako ostatní vědy.

Objektem historie je pro Poppera i pro Hempela minulost a zdá se, že historická vysvětlení (stejně jako hypotetické „ryzí deskripce minulosti“, které ovšem jako cíl historie Hempel odmítá ${ }^{21}$ ) musí odkazovat ke skutečné minulosti. Představa, že reálná minulost jakožto objekt historického zájmu je dopředu strukturovaná, je označována jako historický realismus.

Zejména pak Hempelův text má zásadní význam pro rozvoj analytické filosofie historie, jelikož vzbudil zájem širokého spektra odborníků. Řada vlivných filosofů historie zmiňuje Hempela nejen jako iniciátora budoucí debaty, ale také jako myslitele, který měl výrazný vliv na jejich rané úvahy. Leon J. Goldstein či Murray G. Murphey přiznávají, že byli zpočátku následovníky a žáky Hempela a až později si začali uvědomovat nedostatky modelu pokrývajícího zákona, což je přivedlo $\mathrm{k}$ jejich vlast-

17 Popper (1957, s. 149).

18 Hempel (1942, s. 44).

19 Tamtéž, s. 43.

20 Dewulf (2018, s. 163). Hempelův text je ovšem nezbytné číst také v původním německém kontextu o vztahu vysvětlování a rozumění.

21 Hempel (1942, s. 47-48). 
ní filosofii historie. V ostřejším kontrastu vůči Hempelovi se rozvíjí také jiný myšlenkový proud zahrnující různorodé myslitele zaměřené spíše na lingvistickou strukturu historických textů. Mezi tyto „narativisty“ můžeme počítat myslitele jako A. C. Danto, Hayden White či Frank Ankersmit. Do filosofického diskursu se rovněž vrací angloameričtí filosofové, jejichž úvahy o historii vznikaly před vydáním článku „The Function of General Laws in History“. Mezi nejvýznamnější z těchto myslitelů patří např́klad Michael Oakeshott, Maurice Mandalbaum a Robin G. Collingwood, jehož posmrtně vydané dílo bylo od šedesátých a sedmdesátých let čile komentováno a interpretováno, stejně jako byly nalézány doposud nezveřejněné fragmenty.

Závěrem tohoto oddílu by mělo být zřejmé, že zájem o historické bádání v angloamerickém diskursu byl probuzen zejména dvěma novopozitivistickými badateli, kteří do USA emigrovali ze střední Evropy po zkušenostech s nacistickou a marxistickou ideologií. Jejich motivací bylo vymanění se z ideologických pout a přiblížení historie $\mathrm{k}$ ideálu vědy.

\section{Narativismus a návrat ideologie}

V tomto oddíle se budeme věnovat kritice novopozitivistického př́ístupu a tomu, jak se do filosofického diskursu o historii vrací ideologie, která již nemá roli obávaného strašáka.

Spolu s narativistickým př́stupem $\mathrm{k}$ historii prrichází zásadní odklon od řady motivů, které jsme identifikovali $\mathrm{v}$ předcházející etapě. Filosofové si začínají více všímat jazykové struktury výstupů historické práce a referenčních praktik. Podle Ankersmita tak dochází k „obratu k jazyku“"22 ve filosofii historie. Zvláštní úloha zde patří americkému filosofovi Dantovi, který si začíná všímat zvláštností typických pro jazyk historiků. Tradičním př́íkladem, který Danto uvádí, je věta: „Třicetiletá válka začala v roce 1618." Dle Danta tyto věty odkazují k minulým událostem, avšak je zřejmé, že žádný historický agent nemohl tuto větu pravdivě tvrdit v roce 1618 a v letech bezprostředně následujících. Stejné nejasnosti vykazuje například označení velká válka a první světová válka a obdobné prvky jsou $\mathrm{k}$ vidění také $\mathrm{v}$ jiných historických disciplínách jako např́íklad 
v dějinách filosofie. Jak Danto trefně poznamenává, Tomáš Akvinský by nám patrně nedokázal odpovědět na otázku, jaké to je, být stř̌edověkým filosofem..$^{23}$

V centru Dantova zájmu tak stojí „narativní věty“, tedy věty popisující dávné události s odkazy na události pozdější. Právě narativní věty odlišují historii od hypotetické ideální kroniky, tedy sbírky všech vět o minulosti, které v daný okamžik zapisuje ideální kronikář - dokonalý svědek všech minulých událostí. Historikové nemohou dosáhnout definitivního a úplného popisu minulosti nejen $\mathrm{z}$ důvodu chybějících pramenů, ale právě proto, že sami zkoumají minulost z určitého bodu v dějinách. Historické narativy a teorie jsou tak neustále přepisovány. Jinak ovšem pracují spekulativní nebo substantivní filosofové dějin, kteří se snaží popsat minulé dění z perspektivy hypotetických událostí v imaginární budoucnosti, ke kterým dle nich společnost spěje.

Skutečnost, že historik přistupující k minulým událostem se sám nachází v jiné dějinné situaci a že právě zpětný pohled na nestrukturovanou, chaotickou minulost je typický pro jeho řemeslo, se stává zásadním předpokladem narativisticky orientovaných filosofů historie. Důraz na konstrukci mnohasložkových historických narativů je obzvlášt zřetelný $\mathrm{v}$ dílech Haydena Whita, který předkládá komplexní a inspirativní analýzu toho, jak historikové svobodně přetvářejí kroniku (množinu tvrzení o minulých událostech), přes jednoduchý prŕiběh, až do finální podoby historie, která zahrnuje odlišné explanační strategie, mezi něž patř́ také ideologická implikace. Zatímco v Metahistorii je ideologická implikace jedním z možných způsobů vysvětlení, role ideologie v dalších Whitových dílech je zdůrazněna o poznání více. ${ }^{24}$ Již úvodní Whitovo prohlášení v Metahistorii, podle nějž přistupuje $\mathrm{k}$ historickým dílům primárně jako k literárním artefaktům, ${ }^{25}$ se pro mnohé filosofy stalo dostatečným důvodem k odmítnutí Whitovy koncepce jako relativizující či přímo de-

23 Danto (2013, s. 116). Zdá se, že Dantovy úvahy částečně inspirovaly také významného intelektuálního historika Quentina Skinnera, viz Skinner (2002, s. 49), který je často prezentován jako zastánce názoru, že tvrzení historických agentů bychom měli interpretovat tak, aby agenti samotní s interpretací mohli hypoteticky souhlasit.

24 Viz White $(1975,1978)$ a Domanska (2008).

25 Viz White (1973, s. 2). 
struktivní pro historickou disciplínu. ${ }^{26}$ Třebaže je taková extrémní kritika mnohdy neopodstatněná, ${ }^{27}$ je důležité povšimnout si explicitně definované př́tomnosti různých ideologických ${ }^{28}$ přesvědčení v historických dílech:

\begin{abstract}
„Dokonce i o těch historicích, kteří se nepřihlásili ke konkrétním ideologickým závazkům a kteří potlačili impuls načrtnout explicitní ideologické implikace na základě své analýzy minulých společností, můžeme prohlásit, že pracují v konkrétním ideologickém rámci díky zaujetí pozice proti formě, jaká je historické reprezentaci vlastní.“29
\end{abstract}

Filosofové i historikové mohou namítat, že historie vykazující ideologické zabarvení je zkrátka př́ikladem špatné historie, jelikož historikové cílí na historická fakta a pravdu. ${ }^{30}$ Takový postoj ve své útočné kritice Whita prezentuje historický realista Murphey:
„Většina historiků, které znám, studuje minulost, protože se o ní chtějí něco dozvědět, ne proto, že si představují, jak ji využijí k rozvíjení určité ideologické agendy." ${ }^{31}$

Murphey je ve své rétorice vưči Whitovi nebývale agresivní a obviňuje ho ze zbytečného prohlubování rozdílu mezi procesem historického výzkumu a procesem psaní historiografických textů. Do značné míry tak vyjadřuje rozššřenou a pochopitelnou obavu, že se z historie ve Whitově pojetí vytrácí důraz na faktickou stránku minulosti a na skutečnou minulost. Zároveň si uvědomuje, že korespondence ke skutečné minulosti,

26 Pro přehled viz Kansteiner (1993), Ankersmit (1998) nebo Domanska (1998). Mezi konkrétní a vytrvalé kritiky patří například historik Carlo Ginzburg nebo filosof Murray G. Murphey.

27 Viz Zeleňák, ed. (2013).

28 Pojem ideologie je v dílech narativistů užíván jiným způsobem než v dílech Poppera, který ho užíval spíše jako hodnotící termín a ideologie (zejména marxismus) kritizoval. V dílech Haydena Whita jde o nehodnotící termín referující k soustavě idejí, přesvědčení a postojů. Konkrétní ideologie můžeme hodnotit jako škodlivé či nebezpečné, avšak vždy z pozice jiné ideologie.

29 White (1978, s. 69).

30 White tento postoj ovšem nesdílí. Nejznatelněji se toto projevuje v jeho diskusi o holokaustu, jeho odmítačích a fašistické historiografii. Viz White (1982, s. 133-137), nebo Domanska (2008, S. 19-21).

31 Murphey (2009, s. 131). 
která odlišuje historii od fikce, se u Whita skrývá pod pojmem kronika, kterou historik do narativu přetváří a která obsahuje tvrzení korespondující se skutečnou minulostí. ${ }^{22}$ Neúprosným kritikem Whitovy ideologické složky historie je také italský historik a představitel mikrohistorie Carlo Ginzburg. ${ }^{33}$

Whitův důraz na proměnlivost historických narativů a jejich návaznost na aktuální společenské dění je ovšem něco, co nelze snadno odmítnout. Hayden White brání svůj důraz na ideologickou stránku historie vůči konkrétním námitkám Ewy Domanské v rozhovoru z roku 2008 slovy:

„Historie byla vždy ideologická. To ovšem není na škodu. Je lepší mít pravicovou ideologii než vůbec žádnou. Ideologie přinejmenším ukazuje, že se zajímáte o současnost a o budoucnost.“34

White identifikuje ideologii jako součást historických textů a historiografie. Jednotlivé ideologie samožrejmě posuzujeme na základě našich současných hodnot a přesvědčení, avšak přítomnost ideologie není na závadu, je naopak konstituentem historického textu. White v souvislosti s činností historika zdůrazn̆uje svobodu a volbu, nikoliv rigorózní explanaci jako jeho novopozitivističtí předchůdci a stejně tak rysy typické pro spekulativní filosofii historie neodmítá se stejnou vehemencí jako Danto. ${ }^{35}$ Řadu narativistických motivů pak dále rozvíjí Keith Jenkins, Frank Ankersmit či Paul Roth. Význam Haydena Whita pro reflexi historické disciplíny dnes přijímají také historikové, navzdory počátečnímu odmítání ${ }^{36}$

Zásadní obrat, který ovšem filosofie historie prodělala spolu s obratem k jazyku, je zřetelný už nyní. Snaha zbavit historickou disciplínu ideologických vlivů se otočila ve tvrzení o nevyhnutelné všudypř́tomnosti ideologických úvah a přesvědčení. Toto pojetí nabízí portrét historické disciplíny jakožto diskursu produkujícího různorodé, společensky a po-

32 Tamtéž, s. 129.

33 Zejména Ginzburg (2012).

34 Domanska (2008, s. 20).

35 Danto v roce 2013 přiznává, že s Whitovou filosofií historie sdílí jen velmi málo společných motivů. Přesto jsou oba často řazeni vedle sebe mezi narativisty, viz Danto (2013, s. 117).

36 Např. Horský (2017) nebo Kalela (2012). 
liticky podmíněné narativy, což může sloužit jako plodné podhoubí pro zneužití historického bádání. Skrze koncept kroniky si sice narativisté zachovávají určitý kontakt se skutečnou minulostí, avšak historie, jak White zdůrazňuje, ${ }^{37}$ není věda a nemůže vykročit z ideologického stínu.

Ideologie se tak znovu objevuje v centru zájmu filosofủ historie. Jde však o jinou ideologii než v př́padě Poppera a Hempela. Jde o soustavu idejí, přesvědčení a pojmů, kterou historik uživá při tvorbě historického narativu a bez které nemůže historie existovat.

\section{Antirealismus a historie jako zkoumání}

Některé kritické námitky vůči narativismu již byly nastíněny, avšak $\mathrm{v}$ této kapitole se budeme věnovat jednomu z kritiků narativistického prŕstupu, který se svou kritikou přišel již v počátcích diskuse a jehož vliv je rozpoznatelný také u současných autorů. Americký filosof a Hempelův žák Leon J. Goldstein sice usiluje o zachování historie jakožto vědy, nespouští ze zřetele epistemologické otázky a odmítá se věnovat historii jakožto literárnímu snažení, avšak důsledky přijetí jeho teorie mohou mít pro naše poznání skutečné minulosti ještě fatálnější následky než narativismus.

Goldstein se postupně odklání od zkoumání historického vysvětlování, jak ho načrtnul Hempel, a ostře vystupuje proti některým z raných narativistů, zejména proti L. Minkovi. Jeho intelektuální vývoj je výrazně ovlivněn četbou textů britského filosofa, historika a archeologa R. G. Collingwooda, kterého kriticky rozvijí. Podle Goldsteina sdílí oba zmíněné přístupy (pokrývající zákon a narativismus) podobnou chybu - neberou historickou disciplínu vážně jako zdroj určité znalosti. Oba filosofické př́istupy analyzují nanejvýš výsledné produkty historického bádání, které jsou určené primárně pro laické publikum a své čtenáře seznamují s jeho výsledky, nikoliv s historií jakožto disciplínou. Právě Goldsteinova distinkce mezi superstrukturou historie (prezentací výsledků výzkumu, tedy primárně, avšak nikoliv exkluzivně, texty) a infrastrukturou historie (historickým bádáním, jeho metodami a postupy) se stala jedním

37 Domanska (2008, s. 20). 
z jeho nejcitovanějších příspěvků ${ }^{38} \mathrm{k}$ filosofii historie a respektuje ji řada současných autorů.

Co ovšem může zkoumání infrastruktury historie filosofưm nabídnout? A znamená to, že superstruktura historie není legitimní předmět filosofického bádání a že témata zkoumaná narativisty nejsou vhodným subjektem filosofie historie? To Goldstein nikde přímo netvrdí, naopak trvá na tom, že výsledky historického výzkumu jsou vhodným předmětem úvah, kontemplací, hodnocení, a dokonce můžeme teoreticky polemizovat o tom, zda nám historická znalost nemůže přinášet nějaké ponaučení do budoucna. Nic z toho ovšem není pro historii esenciální, nebot’ jde pouze o její superstrukturu. ${ }^{39}$ To, co Goldstein považuje za centrální téma filosofie historie je historická konstituce ${ }^{40}$ odehrávající se na úrovni infrastruktury historie.

Pro Goldsteina byla od jeho nejranějších děl typická výrazná orientace na proces historického výzkumu, na naši schopnost identifikovat specifické objekty jako instance historického textu či jiného artefaktu a označit je jako důkazy pro určitou teorii o minulosti. Podle Goldsteina je tento komplexní proces esenciální pro historické bádání. Chceme-li ho porovnat s předcházejícími koncepty historie, pak jde o tvorbu kroniky ve formě ne nepodobné vědeckému modelu. ${ }^{41} \mathrm{Zde}$ se ovšem Goldstein zásadně rozchází s celou řadou dalších filosofů historie. Podle Goldsteina je minulost, ke které historikové referují, zásadně odlišná od skutečné minulosti. Nejde jen o tvrzení, že skutečná minulost zkoumaná historiky je nezformovaná a nestrukturovaná, ale jde přímo o tvrzení, že reálná minulost není předmětem historického bádání. Goldstein neřeší otázku ontologické povahy minulosti a stejně tak ji podle něj neřeší ani praktikující historikové. Zároveň se Goldstein nehlásí ke skeptickému stanovisku o povaze minulosti, ani není skeptický ke schopnosti historiků získávat netriviální poznatky

38 Např. Murphey (2009, s. 37), Tucker (2004, s. 168), Kuukkanen (2015, s. 7).

39 Distinkce mezi superstrukturou a infrastrukturou je představena v Goldstein (1976, s. 140-141). Goldstein se k této distinkci vrací a vyvrací některé její dezinterpretace nap̌r. v Goldstein (1986).

40 Termín „konstituce“ je zvolen s ohledem na skutečnost, že Goldstein sám hovoří o „historical constitution“. Goldsteinova pozice je ovšem principiálně konstruktivistická a bylo by tak možné hovořit také o historické konstrukci.

41 Přirovnání historických narativů a teorií o minulosti $\mathrm{k}$ vědeckým modelům (po vzoru Nancy Cartwrightové) se ve filosofické literatuře objevuje často, viz White (1978, s. 80). Cartwrightovou pak přímo zmiňuje Murphey (2009, s. 54) či Tucker (2004, s. 164). 
o světě. Naopak se domnívá, že vzdát se představy reference k reálné minulosti je jediný způsob, jak se může historie vyhnout oprávněným skeptickým námitkám vůči její schopnosti informovat nás o svém předmětu. Goldstein je představitelem historického antirealismu.

Goldstein si je velmi dobře vědom toho, že se železnou pravidelností vyjadřujeme přesvědčení o platných historických teoriích (či narativech) jakožto referujících $\mathrm{k}$ reálným entitám a událostem v minulosti, avšak toto považuje za nedostižný ideál. To, co historické teorie vysvětlují, jsou, jen a pouze, současná empirická data, která byla identifikována jako historický do̊kaz a vyžadují historické vysvětlení. Užívání korespondenční teorie pravdy v souvislosti s historií podle Goldsteina pouze vyjadřuje naději, že konstituovaná historická minulost odpovídá reálné minulosti. Goldstein se na mnoha místech vyjadřuje, že je zcela přirozené takto historii rozumět, avšak na základě řady analýz konkrétních historiografických děl (mimo jiné také Collingwoodovy Roman Britain) ${ }^{42}$ dochází k tomu, že nejde o legitimní obraz historického výzkumu. Potřeba historického výzkumu podle Goldsteina vychází z faktu, že v našem světě jsou předměty (artefakty, texty), které ke svému vysvětlení vyžadují postulování nám jinak nepřístupné minulosti. ${ }^{43}$ Tuto minulost nemůžeme jednoduše poznávat, ale můžeme usilovat o konstituci modelu, který nám pomůže vysvětlit př́itomnost celé řady empirických dat. Takový model (historická minulost) je tedy závislý na empirických datech, které dokážeme v současnosti identifikovat a využít jako historický důkaz k rozššřrení aktuálně přijímaného modelu historické minulosti. Historik samozřejmě vždy ke své práci přistupuje z určité pozice a s určitou znalostí historické minulosti, avšak může usilovat o objevení a implementaci nového důkazu či o kritiku doposud přijímaných teorií.

Goldsteinovo pojetí historické disciplíny čelí mnoha námitkám. Bývá mu např́klad často vytýkáno, že k tomu, aby podpořil svůj historický antirealismus, volí zcela účelově příklady z dávné minulosti, které obzvlášt trpí nedostatkem důkazů. ${ }^{44}$ Toto lze ovšem snadno odmítnout s tím, že

42 Goldstein (1996, s. 302).

43 Srovnej Horský (2017, s. 344).

44 Goldstein sám na tuto námitku v roce 1986 odpovídá pouze tak, že záměrně volil takové př́íklady, nebot' dobře ilustrují jeho pozici. Takovou odpověd' lze ovšem považovat za nedostatečnou. Viz Goldstein (1986, s. 86-87). 
ucelená filosofická teorie o historii by měla být schopna pokrýt všechny instance historického bádání a není tudíž možné vyloučit starší dějiny jakožto nerelevantní. Zároveň se nedá říci, že by Goldsteinovy závěry neplatily také pro nedávnou historii. Skutečnost, že si určité události sami pamatujeme, popřípadě že máme $\mathrm{k}$ dispozici pestrou škálu empirických dokladů včetně dokumentů, videozáznamů či digitálních dat, není pro historika obzvlášt' směrodatná. Historik totiž nebude ke svým vzpomínkám (popř́ípadě $\mathrm{k}$ výpovědím očitých svědků) přistupovat jako k reálné minulosti per se, ale spíše jako k důkazu, který musí být podroben kritickému zkoumání optikou aktuální historické disciplíny. Množina přijímaných důkazů se postupně rozšiřuje od 19. století a neustále nové a nové typy důkazů jsou akceptovány. Politická historie tak může využívat nejen deníků, dopisů, ale nově musí zohlednit také chování voličů na sociálních sítích a Twitterovou komunikaci. Zároveň nám v době post-faktické musí být zřejmé, že nekritické přejímání informací z takových zdrojů není možné a různé narativy politicky orientovaných informačních médií musí být podrobně analyzovány $\mathrm{v}$ relaci $\mathrm{k}$ dalším datům. Můžeme se ovšem takto dobrat reálné minulosti?

Historický antirealista opět odpovídá, že nikoliv, a musí tak čelit další námitce, která má mnohé společné s debatou o ideologii u Haydena Whita. Zastánci historického realismu by mohli namítat, že rezignace na korespondenci historické minulosti s reálnou minulostí ochuzuje historii o její etický rozměr. V článku „The past of our present“45 (jehož název patrně odkazuje ke Collingwoodovu tvrzení „all history is contemporary history“46), Goldstein uznává, že odmítnutí relevance reálné minulosti pro historické bádání může zdánlivě oslabit naše morální soudy o minulých událostech. Tento důsledek ovšem odmítá, nebot historická minulost je stále něco intersubjektivně sdíleného a něco, k čemu se vztahujeme. Zároveň je třeba si uvědomit, že historická minulost je u Goldsteina vysvětlením př́tomných empirických dat a je výsledkem systematické činnosti historiků, mezi nimiž panuje velká míra shody. Právě tato skutečnost dává Goldsteinovi nástroj k odmítnutí např. popírače holokaustu $\mathrm{s}$ větší razancí a rozhodností, než učinil Hayden White. Mluvíme-li totiž

45 Goldstein (1996, s. 241-253).

46 Collingwood (1994, s. 202). 
o minulosti, pak mluvíme o historické minulosti, tedy o komplexním intersubjektivním modelu, na jehož historické konstituci se podílí široké spektrum odborníků a jenž vysvětluje přítomná empirická data, jejichž explikace by jinak nebyla možná. Tato historická minulost není totožná s reálnou minulostí, ale je výsledkem současného systematického zkoumání současného světa. Historická minulost, jakožto model, pak hraje roli v dalších intelektuálních aktivitách zahrnujících narativní reprezentaci tohoto modelu, vysvětlení jeho jednotlivých prvků či další způsoby reflexe.

Goldsteinovy postř̌ehy o povaze historického bádání jsou do různé míry rozvíjeny v dílech řady současných autorů, mezi něž patří např. Aviezer Tucker, Jouni-Matti Kuukkanen či Murray G. Murphey. Velký vliv má zejména jeho distinkce mezi superstrukturou a infrastrukturou historie, menší zájem pak vzbudil jeho historický antirealismus. Pozici blízkou Goldsteinovu antirealismu rozvíjí také Paul Roth ${ }^{47}$ a v prostředí historických přirodních věd Derek Turner ve své knize Making Prehistory: Historical Science and the Scientific Realism Debate..$^{48}$

Filosofie historie a historiografie prodělala skutečně zajímavý vývoj, který můžeme velmi volně shrnout $\mathrm{v}$ následujícím narativu: Zatímco Popper a Hempel považovali ideologii za něco, čeho se musí historikové, pokud možno, vyvarovat, a zaměřovali se zejména na otázky historické explanace, narativisté považují ideologii a společenské zasazení historiků za něco, co figuruje jako významný konstituent historického textu či narace - tedy předmětu zájmu filosofie historie. Historické narace ovšem nejsou ryzí fikce a mají vztah ke skutečné minulosti skrze kroniku. Narativisté obohatili filosofii historie o cenné analýzy jazyka, jejž historikové uživají, a o analýzy toho, jak historikové syntetizují výsledky svého bádání do podoby uceleného textového výstupu určeného pro širší publikum.

Goldstein ovšem tento vývoj kritizuje a identifikuje společnou chybu: Hempel i narativisté nedokáží odhlédnout od textů, které historikové produkují, a nevšímají si konstituce přijímaných historických faktů - toho, jak minulost poznáváme či vytváŕíme. Srovnáme-li obraz his-

47 Např. Roth (2012).

48 Turner (2007). 
torické disciplíny, který nabízí Goldstein, s vizí Haydena Whita, pak je zřejmé, že Goldsteina zajímá to, jak historik získává kroniku, tedy fáze předcházející tvorbu historie podle narativistické koncepce. Podle Goldsteina ovšem nelze tvrdit, že tvrzení obsažená v kronice referují ke skutečné minulosti, ale slouží primárně k vysvětlení přítomných důkazů. Historikové konstituují historickou minulost na základě empirických dat identifikovaných jako pozůstatky minulosti a důkazy pro určitou teorii o historické minulosti, jež je odlišná od skutečné minulosti. Navzdory tomu, že se Goldstein pečlivě snaží ukotvit svou filosofickou koncepci v historické praxi a ve vztahu důkaz - teorie, dochází u něj k radikálnímu kroku - k odmítnutí relevance skutečné minulosti pro historické bádání. Situovanost historika je pro takovou teorii zásadní. Třebaže Goldstein vliv ideového pozadí historika na finální podobu jeho výstupu příliš nerozvádí, zcela zřetelně si jej uvědomuje.

Závěrem této sekce můžeme konstatovat, že Goldsteinův antirealistický historický konstruktivismus, třebaže zaměřený proti historickému narativismu, zcela odsouvá představu reálné minulosti jakožto prubířského kamene historického bádání. Historická minulost je konstituovaná (konstruovaná) k tomu, aby vysvětlila současná empirická data. Rozpoznání a identifikování těchto dat je pak teoreticky podmíněné a je třeba se soustředit na specifika historické praxe a historického diskursu. Tato témata dnes rozvíjí zejména J. M. Kuukkanen a P. Roth.

\section{Příběh, výzkum nebo kritické myšlení?}

Tato závěrečná část práce je věnována zamyšlení nad tím, co nám může filosofie historie nabídnout tváří v tvář post-faktické situaci, které nyní čelíme. Historické bádání je bezpochyby komplexní a systematickou činností, která zkoumá celou řadu oblastí (politické dějiny, dějiny filosofie, dějiny každodennosti, dějiny literatury, dějiny sportu atd.) prostřednictvím obsáhlé množiny empirických dat (texty, fragmenty, artefakty, videozáznamy, digitální materiál, výpovědi svědků), využívá široké spektrum metod (interpretace, matematické modelování textu, spektrografická analýza, experimentální archeologie, orální historie, komparace atd.) a produkuje různorodé výstupy (texty, ilustrace, prostorové modely, rekonstrukce v původ- 
ní velikosti či interaktivní aplikace). Zároveň je ovšem nezbytné s vážností respektovat výsledky narativistické filosofie historie, která zkoumá zvláštní povahu historických věd, zpochybňuje představu nadčasové historické objektivity ve formě ideální kroniky, poukazuje na kulturní, geopolitickou a dějinnou situovanost historika a zdůrazňuje př́tomnost ideologických implikací v historických narativech. Historické narativy se nutně proměňují v čase, a to se děje nejen jako reakce na objevení či identifikaci nového důkazu, ale také vlivem společenských a politických změn. Historické narativy rovněž vykazují pluralitu a řady otázek (zahrnující př́ičiny konfliktů, revolucí, kolapsů, návazností intelektuálních tradic, původu určitých společenských praktik, formování národních států atd.) potencionálně postrádají vyhlídku na jednoznačné a definitivní rozřššní.

Nastíněná vize historie jakožto disciplíny zdánlivě nedává přílišnou naději v boji proti dezinformacím a zneužívání historických teorií v politickém boji o veřejné mínění. Fluidní povaha historických narativů se dá snadno zneužít ve prospěch narativo̊ politických, přičemž je možné říci, že mezi nimi neexistuje jasně vymezitelný přechod. Historické teorie, vyučované ryze narativním přístupem na základních školách, pomáhají dotvářet naši národní či občanskou identitu a vytvář́me si k nim specifický vztah. Narušování a kritika těchto narativo̊ nemusí mít vždy podobu vědecké diskuse, naopak může mít formu boje proti establishmentu a prosazování domnělých hodnot našich předků. Historický revizionismus rovněž často reaguje na aktuální společenské problémy kritikou dosavadních narativů (např. těch, které jsou vyučovány na školách), což může vyvolávat efekt zpětného rázu (backfire effect) a odmítavý efekt k takovým revizím, jež posilují politický narativ odmítaný částí společnosti, což dále vede k posílení kompetitivních narativů. Třebaže narativisté trvají na určitém pojítku mezi skutečnou minulostí a historickými texty, jejich důraz na svobodu historika v jeho tvorbě sice dokáže zachytit pluralitu historických interpretací, ale neposkytuje jednoduché vodítko pro hodnocení historických narativů z hlediska „přesnosti“ či „autentičnosti“.

Může nám nějak pomoci příklon k historickému antirealismu? Vzdáme-li se skutečné minulosti jakožto prubiŕrského kamene historického bádání, neocitáme se nutně ve slepé uličce. Historie nám má vysvětlit 
přitomnost určitých empirických dat, pro jejichž explikaci potřebujeme komplexní model minulosti, která je konstruovaná, nikoliv nahlížená. Historikové pak přijímají takové narativy (modely), jež pod kritickým drobnohledem dokážou vysvětlit široké spektrum empirických dat a zároveň vykazují další epistemické ctnosti jako je koherence, přesnost či rozsah. ${ }^{49}$ Třebaže je možné, že se nikdy nedovíme, zda tyto modely odpovídají skutečné minulosti, a jsme tak nuceni operovat $\mathrm{s}$ řadou kompetitivních teorií, můžeme stále usilovat o to nejlepší (hodnoceno dle epistemických ctností) vysvětlení daných dat. Nabízí se tak možnost specifikovat skutečnost, že mezi historiky panuje signifikantní konsensus o řadě témat, jako indikátor ověřené historické znalosti. Toto řešení naznačuje již Goldstein $^{50}$ a do podoby komplexní teorie $\mathrm{v}$ rámci filosofie historiografie jej pak dovádí Aviezer Tucker. ${ }^{51}$

Koncepce historického antirealismu působí ve srovnání s lidovým (realistickým) pohledem na historii krajně neintuitivně. Mưže ovšem přinášet cenné ponaučení o tom, jak historii vyučovat a na které prvky klást důraz. Narativní způsob sdělování výsledků historického bádání je pravděpodobně nejvhodnějším způsobem předávání historických poznatků, avšak přistupuje-li historik $\mathrm{k}$ historickému textu jako $\mathrm{k}$ důkazu, pak je jeho cílem právě překonání a abstrahování narativních prvků. Historie je především současným zkoumáním a kritickou činností. Historik sám je při práci s artefakty, texty a jinými důkazy konfrontován s řadou dezinformací, falešných zpráv a ideologických implikací. Při rozhovorech s pamětníky si musí být vědom celé řady kognitivních zkreslení a musí jejich znalost zahrnout do své metodologie. Historický výzkum na úrovni Goldsteinovy infrastruktury historie je do značné míry shodný s kritickým myšlením tak, jak mu běžně rozumíme v debatách o době post-faktické. Od současného uživatele sociálních sítí se vyžaduje obdobně kritický př̌́stup ke zdrojům informací jako $\mathrm{v}$ případě historika. Je vhodné připomenout vyjádření významného anglického historika Davida Huma z jeho Dějin Anglie:

49 Viz Tucker (2004, s. 254-255).

50 Viz Goldstein (1996, s. 252-253).

51 Viz Tucker (2004, s. 23-45). 
„Úděl historie je rozlišovat mezi zázračným a úžasným; odmítnout to první ve všech světských a lidských vyprávěních; pochybovat o tom druhém; a, jsme-li k tomu zavázáni skrze nezpochybnitelné svědectví, jako v tomto př́padě, přiznat přítomnost něčeho neobyčejného, přijmout alespoň to, co je konzistentní se známými fakty a okolnostmi. “52

Porovnáme-li toto vyjádření $\mathrm{s}$ Humovou filosofickou kritikou zázraků v jeho Zkoumáních, pak je zřejmé, že Hume přisuzuje historikovi zcela zásadní kritickou roli v posuzování toho, co lze a co nelze považovat za zázračné. ${ }^{33}$

Postavíme-li vedle sebe dva novinové články v periodikách na opačných koncích politického spektra pokrývající „stejnou“ událost zcela odlišným způsobem a s protichůdnými hodnoceními, pak se naše uvažování překvapivě podobá váhavému postoji historika analyzujícímu dva prameny podávající rozporný výklad. Nezanedbáváme tedy př́ležitost propagovat kritické myšlení a možnost naučit opatrnosti při práci s různými zdroji, když historii prezentujeme jako jeden dlouhý příběh o minulosti?

Lidové chápání historie jakožto vyprávění o událostech v minulosti do značné míry diktuje to, jak vypadají hodiny dějepisu na školách. Třebaže klademe důraz na chápání historických událostí „v kontextu“, je třeba pamatovat na to, že nemáme $\mathrm{k}$ dispozici žádný definitivní historický kontext a ve skutečnosti volíme pouze mezi dostupnými modely, které pouze činíme relevantními na základě cílového narativu. Taková relativizace historie ovšem není, alespoň na nižších vzdělávacích stupních, žádoucí, stejně jako není možné žáky základních a středních škol učit aktuální historické metodologii. Avšak nápad využít širší spektrum učebních materiálů a konfrontovat studenty s prameny a důkazy nevyplývá

52 Hume (1983, s. 276).

53 Je třeba mít na paměti, že zde prezentovaná snaha ukázat Davida Huma jakožto koherentního myslitele, nerozlišujícího mezi užitím pojmu ve svém historickém a ve svém filosofickém textu a neměnícího mezi jednotlivými díly svá stanoviska, může být zavádějící. Do skutečné Humovy mysli v minulosti nemáme př́stup a můžeme pouze usilovat o rozpoznání intencí v dostupných a identifikovaných textech. Interpretujemeli Huma jako absolutně koherentního a neomylného, pak pravděpodobně podléháme mýtu koherence, jak ho vymezil Quentin Skinner. Viz Skinner (1969, s. 16-18). 
pouze z historického antirealismu, nebot' snaha o implementaci nových pedagogických postupo̊ je považována za perspektivní také v pedagogické literatuře. ${ }^{54}$ Van Hover et al. pak zmiňují, že:
„Vyučování konceptu důkazu k podpoře růstu znalostí a kritic- kého interdisciplinárního myšlení je vyzývavým, ale zásad- ním komponentem ve výuce budoucích občanů. “55

Učitelé si uvědomují, že takový přístup školí žáky kritickému myšlení a zároveň jim umožňuje lépe přiblížit výsledky historického bádání. Vyučovací hodiny tak jsou více interaktivní a pro studenty prínosnější. Tento prrístup nemůže samozrejmě zcela nahradit ryzí předávání předem ošetřených historických narativů, avšak rozšiřuje obyčejný dějepis o aspekt kritického myšlení, kterého si dnes v době post-faktické velmi ceníme. Školství také může využít široké nabídky výstupů historického bádání, nikoliv pouze texty. Je možné do výuky implementovat návštěvu muzeí, skanzenů a dalších historických rekonstrukcí, které názorněji ukazují vztah historických reprezentací $\mathrm{k}$ důkazům a proces historické konstituce. Studium antické historie tak může být doplněno o cvičení s fragmentárními a protiřečícími si prameny, zatímco na propagandistických materiálech druhé světové války (popř. studené války) je možné ukázat historické prameny, které úmyslně klamou.

Ryzí předávání kanonizovaných narativu je ve školství př́ítomno nejen $\mathrm{v}$ hodinách dějepisu, ale také $\mathrm{v}$ případě společenských věd a dějin filosofie. Takový př́stup, bez toho, že by byl doplněn o metodologické přesahy, vzbuzuje dojem jediného správného narativu o skutečné minulosti, aniž by byla zřejmá situovanost současného člověka jakožto poznávajícího subjektu a také ideologické pozadí předávaných vyprávění. Doplnění výuky historie o zprostředkovanou interakci s prameny a důkazy tuto potencionálně nebezpečnou iluzi nabourává a doplňuje výuku o trénink v kritickém myšlení, které se v éře dezinformací, falešných zpráv a manipulací stává nezbytnou dovedností.

54 Např. Labischová (2015), van Hover a kol. (2016) nebo Barton (2003). Pro experimentální výzkum týkající se výuky kritického myšlení v rámci historického kurzu, viz McLaughlin \& McGill (2017).

55 Van Hover et al. (2016, s. 216). 


\section{Literatura}

Ankersmit, F. R. (1986): „The Dilemma of Contemporary Anglo-Saxon Philosophy of History." History and Theory 25 (4): 1-27.

Ankersmit, F. R. (1998): „Hayden White's Appeal to the Historians.“ History and Theory 37 (2): 82-193.

Barton, K. C. \& Levstik, L. S. (2003): „Why Don't More History

Teachers Engage Students in Interpretation?" Social Education

67 (6): $358-361$.

Bezpečnostní informační služba (2018): „Výroční zpráva Bezpečnostní informační služby za rok 2017." In Bezpečnostní informační služba [online] [cit. 24. 5. 2019]. Dostupné z: https://www.bis. cz/public/site/bis.cz/content/vyrocni-zpravy/2017-vz-cz.pdf.

Birner, J. (2018): „Karl Popper's The Poverty of Historicism after 60 years." Metascience 27 (2): 183-193.

Collingwood, R. G. (1994): The Idea of History. Oxford University Press, Oxford.

Danto, A. C. (2013): „Hayden White and Me: Two Systems of Philosophy of History. "In: Philosophy of History After Hayden White, ed. R. Doran, Bloomsburry, London, 2013, s. 109-117.

Dewulf, F. (2018): A Genealogy of Scientific Explanation The Emergence of the Deductive-Nomological Model at the Intersection of German Historical and Scientific Philosophy. Thesis. Ghent University, Ghent.

Domanska, E. (1998): „Hayden White: Beyond Irony.“ History and Theory 37 (2): 173-181.

Domanska, E. (2008): „A conversation with Hayden White.“ Rethinking History 12 (1): 3-21.

Ginzburg, C. (2012): Thread and Traces. University of California Press, Berkeley.

Goldstein, L. J. (1962): „Evidence and Events in History.“ Philosophy of Science 29 (2): 175-194.

Goldstein, L. J. (1976): Historical Knowing. University of Texas Press, Austin, London. 
Goldstein, L. J. (1986): „Impediments to Epistemology in the Philosophy of History." History and Theory 25 (4): 82-100.

Goldstein, L. J. (1996): The What and the Why of History:

Philosophical Essays. Brill, Leiden.

Harsin, J. (2018): „Post-Truth and Critical Communication Studies.“ In

Oxford Research Encyclopedia of Communication, ed.

J. Nussbaum. Oxford University Press, Oxford, s. 1-36.

Hayhoe, K., Basurto, X. \& Brossard, D. (2017): „Post-Truth

Predicaments." Nature 541: 425-27.

Heit, H. (2018): „,there are no facts...': Nietzsche as Predecessor of

Post-truth?" Studia Philosophica Estonica 11: 44-63. Dostupné

na: https://ojs.utlib.ee/index.php/spe/article/view/14404.

Hempel, C. G. (1942): „The Function of General Laws in History.“ The Journal of Philosophy 39 (2): 35-48.

Hempel, C. G. (1967): Philosophy of Natural Science. Pearson

Education; český překlad (P. Hromek) Filosofie př́rodních věd, Červený Kostelec, Ostrava, 2015.

Horský, J. (2017): „Co si dnes počít s narativními kritikami dějepisectví?" Dějiny - Teorie - Kritika (2): 335-352.

Horský, J. (2008): „Co je to „národní rámec‘? Několik poznámek, otázek a úvah na okraj článku Miloše Řezníka." Dějiny - Teorie Kritika (2): 274-292.

Hume, D. (1983): History of England: From the Invasion of Julius Caesar to the Revolution in 1688. Liberty Fund, Indianopolis.

Kalela, J. (2012): Making History: The Historian and Uses of the Past. Palgrave Macmillan, New York.

Kansteiner, W. (1993): „Hayden White's Critique of the Writing of History." History and Theory 32 (3): 273-295.

Kuukkanen, J. M. (2015): Postnarrativist Philosophy of Historiography. Palgrave Macmillan, London.

Labischová, D. (2015): „Historický pramen a badatelsky orientované učení v německých učebnicích dějepisu. "Historica. Revue pro historii a př́buzné vědy 6 (2): 196-211. 
McLaughlin, A. C. \& McGill, A. E. (2017): „Explicitly Teaching Critical Thinking Skills in a History Course." Science and Education 26 (1-2): 93-105.

Murphey, M. G. (2009): Truth and History. State University of New York Press, New York.

Nowell-Smith, P. H. (1977): „The Constructionist Theory of History.“ History and Theory 16 (4): 1-28.

O'Sullivan, L. (2006): „Leon Goldstein and the Epistemology of Historical Knowing." History and Theory 45 (2): 204-228.

Popper, K. R. (1957): The Poverty of Historicism. The Beacon Press, Boston.

Rosenberg, A. (2011): The Aheist's Guide to Reality. W. W. Norton \& Company, New York.

Roth, P. A. (2012): „The Pasts.“ History and Theory 51 (3): 313-339.

Roth, P. A. (2017): „Essentially narrative explanations.“ Studies in History and Philosophy of Science 62: 42-50.

Skinner, Q. (1969): „Meaning and Understanding in the History of Ideas." History and Theory 8 (1): 3-53.

Skinner, Q. (2002): Visions of Politics, Volume I: Regarding Method. Cambridge University Press, Cambridge.

Smith, A. D. (2000): The Nation in History: Historiographical Debates about Ethnicity and Nationalism. Polity Press, Cambridge.

Špecián, P. (2016): „Konec se blíží? Kritické připomínky k teorii kolapsů." Teorie vědy. Theory of Science 38 (4): 425-448.

Trout, J. D. (2002): „Scientific Explanation And The Sense Of Understanding." Philosophy of Science 69: 212-233.

Tucker, A. (2004): Our Knowledge of the Past: A Philosophy of Historiography. Cambridge University Press, Cambridge. Turner, D. (2007): Making Prehistory: Historical Science and the Scientific Realism Debate. Cambridge University Press, Cambridge.

Van Hover, S., Hicks, D. \& Dack, H. (2016): „From Source to Evidence? Teachers' Use of Historical Sources in Their Classrooms." The Social Studies 107 (6): 209-217. 
White, H. (1973): Metahistory: The Historical Imagination in Nineteenth-Century Europe. The Johns Hopkins University Press, Baltimore.

White, H. (1978): Tropics of Discourse. Essays in Cultural Criticism. The John Hopkins University Press, Baltimore.

White, H. (1982): „The Politics of Historical Interpretation: Discipline and De-Sublimation." Critical Inquiry 9 (1): 113-137.

Wright, G. H. (1971): Explanation and Understanding. Routledge

\& Kegan Paul, London; český překlad (P. Urban a kol.)

Vysvětlování a rozumění, Filosofia, Praha, 2012.

Zeleňák, E. (2015): „Úvod do kritickej filozofie histórie I.“VERBUM vydavatelstvo KU, Ružomberok.

Zeleňák, E., ed. (2013): Mnohotvárnost’ Haydena Whita. Chronos, Bratislava.

\begin{abstract}

\section{Role of History in the Era of Post-truth}

What is the role of history in the age of post-truth? Can philosophy of history help us to hedge against deliberate misuse of historical narratives on ideological grounds? This paper aims to inquire into the philosophical reflections of history and their relation to ideologies. It is shown that during the inception of this field of philosophy, philosophers like Karl Popper or C. G. Hempel aimed to eliminate political and ideological colouring from history. However, the narrativist insight of Hayden White implies that such task is unattainable and historical writing is necessarily ideological. Antirealist philosophy of history, embodied by L. J. Goldstein, even discarded the real past as a goal of historical research and accented the situatedness of historians in relation to their evidence. It is argued that the outlined version of historical antirealism approaches history as a present kind of inquiry that shares many features with critical thinking and focuses mainly on the examination of empirical data that require the postulation of an inaccessible past. This resemblance should be highlighted by teaching history as an inquiry, not a mere story.
\end{abstract}

Key words: philosophy of history, narrativsm, antirealism, critical thinking

Černín, D. (2019): „Role historie v době post-faktické.“ Filosofie dnes 11 (1): 116140. Dostupné z www.filosofiednes.ff.uhk.cz 